\title{
Food of the Striped Field Mouse in Different Types of Urban Green Areas
}

\author{
Joanna BABIŃSKA-WERKA
}

\begin{abstract}
Babińska-Werka J., 1981: Food of the striped field mouse in different types of urban green areas. Acta theriol., 26, 17: 285-299 [With 2 Tables \& 4 Figs.]

Studies were made of the food consumed by the striped field mouse Apodemus agrarius (Pallas, 1771) living in two urban green areas in Warsaw: the Orthodox Cemetery and Eazienki Park, and also in a suburban area at Białołeka. Plant food predominated over animal food in the diet of A. agrarius. Mice living under urban conditions have a more homogeneous diet than those from suburban areas. This was manifested in the greater proportion of tree seeds in the diet of urban mice and less frequent consumption of the seeds of herb layer plants, the predominance of grasses in the green plants' food component and predominance of insects, particularly of their larval forms in the animal food component. The diet of urban mice was more caloric, which may account for the greater weight of rodents in the city in comparison with mice living on suburban areas.

[Dept. of Wildlife Management, Warsaw Agricultural University, Rakowiecka 26/30, 02-528 Warszawa, Poland].
\end{abstract}

\section{INTRODUCTION}

Apodemus agrarius (Pallas, 1771) is a non-synanthropic rodent often found in urbanized areas. Long-term studies on urban populations of this species revealed a large number of features distinguishing them from populations living in a suburban habitats (Andrzejewski, BabińskaWerka, Gliwicz \& Goszczyński, 1978, Babińska-Werka, Gliwicz \& Goszczyński, 1979, 1981). One of the important characteristics of urban habitats of Apodemus agrarius is the different composition of their biocenoses then in suburban areas. In comparable areas outside the city both the flora and invertebrate fauna are different, which affects the diet of the field mice.

There are few studies on the food of Apodemus agrarius (Sviridenko, 1944; Naumov, 1948; Holišová, 1967) and they are not concerned with diet of mice living in urban habitats. Hence the purpose of the present study is to analyze food composition of field mice living in town, and to find differences between the diet of these rodents living under urban and suburban conditions. 


\section{STUDY AREA, MATERIAL AND METHODS}

The studies were carried out in Warsaw in two urban green spaces: in Łazienki Park (together with the Botanical Gardens) and in the Orthodox Cemetery. Łazienki Park is situated in the centre of Warsaw, and the Orthodox Cemetery in the eastern part of the city at a distance of approximately $3 \mathrm{~km}$ from the centre. The control area in relation to the urban areas was the suburban study area at Bialolęka, to the north of Warsaw and about $20 \mathrm{~km}$ from the city centre.

In many of the analyses the diet of mice from two urban green areas was treated jointly and contrasted with the diet of mice in the suburban population.

Łazienki Park, together with the adjoining Botanical Gardens, occupies an area of 50 ha and is surrounded by busy streets and compact blocks of housing. The park is covered with the vegetation characteristic of old parks: groups of trees and shrubs with large grassy areas. From the species composition and structural aspects the vegetation is similar to the Tilio-Carpinetum association. The trees in groups reach densities of up to $90 \%$ and bushes up to $75 \%$, which results in considerable shade and consequently a very poor herb layer. Characteristic trees here are Acer platanoides, Tilia cordata, Carpinus betulus, Aesculus hippocastanum, Robinia pseudacacia and Populus alba. The grassy areas included deformed Galinsogo-Setarietum habitats and associations with Poa annua and Agrostis canina. The grassy areas are regularly mown and leaves of trees raked up in the autumn.

The Orthodox Cemetery covers an area of 12 ha, is adjoined by a busy street, housing and from one side by apark. Although the vegetation is artificially planted it is similar to the Tilio-Carpinetum association. The herb layer forms a mosaic of patches and is more luxuriant than in Eazienki Park, since the trees in groups reach densities a maximum of $80 \%$. The Galinsogo-Setarietum association occurs in this study area with Galinsogo parviflora as the dominant species, and the association with Poa annua. The Orthodox Cemetery is much less frequented by humans than Łazienki Park.

Białołęa is a typical suburban area, with separate dwellings and small farms. There is little traffic in the streets. The studies were made in habitats of Tilio-Carpinetum and Circaeo-Alnetum (Roo-Zielińska, in press). Associations of the Querco-Fagetea class occur there, with the species characteristic of mesophyllous deciduous tree stands, and also weed associations of cereal crops (Secalietea), fertile meadows and pastures of the Molinio-Arhenatheretea class.

The studies were carried out from 1977-1979 during three trapping periods: spring (April-June), autumn (September-October), and winter (January-March). A total of 187 field mice were caught (Table 1). Field mice were caught in snap-traps, set out in the most suitable places. The mice were weighed, dissected, their sex and reproductive condition defined, and stomachs preserved for further analysis.

The diet of the mice was analyzed by means of a modified version of Holišová's method $(1966,1971)$. The excised stomachs were preserved by means of drying at a temperature of $50^{\circ} \mathrm{C}$, for several days. Later prior to their examination the stomachs were soaked in water for 24 hours, then opened, inspected under a binocular eyepiece and their contents identified. The stomach contents were placed in a Petri dish, water added, then thoroughly mixed. Several drops of the suspension were placed on reference slides and examined under a microscope with 
magnification $5 \times 40$. In all, ten entirely separate fields of vision were analyzed. Three food fractions were distinguished: seeds, the upper vegetative parts of plants and food of animal origin. In order to calculate the percentage formed by the various food fractions in the whole of the stomach contents a grid was placed in the microscope eyepiece, dividing the whole field of vision into 100 smaller fields.

For identification of animal remains the whole stomach contents were analyzed under a binocular eyepiece. The method used for identifying animal remains is given in the paper by Babinska-Werka \& Garbarczyk (1981).

Control reference slides were made in order to identify seeds, the upper vegetative parts of herbs found in the stomachs. They were prepared in the following way. Above-ground parts and seeds of many herbs were collected from the study areas and fed to captive field mice, each of the plant species separately for three days. In the case of some plant species the diet was insufficient and a high mortality occured among the mice fed with them. Therefore it was necessary to prepare from flour, margarine and water a stiff dought to which finely chopped tissues and crushed seeds of different plant species were added, according to the "cafeteria test" method (Górecki \& Gębczyńska 1962; Drożdż, 1966). Pieces of dough with the different plant species were supplied to the mice for 3 days, than glycerine reference slides of their stomach contents were made by placing on the slides the remains of herbs' tissues and the starch grains characteristic of different seeds. A total of 32 control reference slides were made from seeds and 44 from the upper parts of herbs. In addition a series of reference slides was made from different parts of these plants (stems, flowers, roots and seeds) directly after collecting them from the field (without passing them throught alimentary tract of mice).

Using phytosociological records it was found that as many as 161 plant species were included in the flora of the study areas. As it was impossible to make control reference slides from all the plants, they were made from those species only which occurred in all three study areas.

These control reference slides were used for identification of plant remains found in stomachs of free living mice. In order to identify characteristic starch grains, seeds were treated with the Lugol's reagent before examination.

\section{DIET OF THE FIELD MOUSE}

Field mice feed on food of animal and plant origin. Frequency of occurrence of the three components distinguished (seeds, upper vegetative parts of herbs and animal food) differed in the food of rodents from different areas (Table 1). Seeds and animal components were found in the majority of the stomachs, while the green parts of plants were encountered least frequently. Thus all the stomachs contained seeds, regardless of the place from which the mice were obtained, whereas in the city the percentage of stomachs containing animal food was about $84 \%$ and was slightly higher (differences statistically non-significant) than outside the city at Białolęka, where this food component was found in $71 \%$ of the stomachs. The reverse applies for the green parts of 
Tabela 1

Description of the stomach contents of Apodemus agrarius inhabiting different urban green areas.

\begin{tabular}{|c|c|c|c|}
\hline & Białołęka & $\begin{array}{l}\text { Orthodox } \\
\text { Cemetery }\end{array}$ & $\begin{array}{l}\text { Eazienki } \\
\text { Park }\end{array}$ \\
\hline $\begin{array}{l}\text { Number of stomachs examined } \\
\% \text { of stomachs containing seeds } \\
\% \text { of stomachs containing }\end{array}$ & $\begin{array}{c}68 \\
100.0\end{array}$ & $\begin{array}{l}78 \\
98.7\end{array}$ & $\begin{array}{l}43 \\
97.8\end{array}$ \\
\hline green parts of plants & $48.5^{1}$ & $23.3^{1}$ & $25.6^{1}$ \\
\hline$\%$ of stomachs containing animal food & $71,2^{2}$ & $83.3^{2}$ & $83.7^{2}$ \\
\hline
\end{tabular}

plants. At Białołęka almost half the individuals of Apodemus agrarius examined supplemented their diet with this type of food, whereas in the city only $1 / 4$ of the total number did so (differences statistically significant $p \leqslant 0.05$, Student $t$ test).

The rodents' diet was predominately a mixture, the only food fraction occurring solely being seeds. The mixed food in the rodents' stomachs consisted either of two components (seeds and animal food or seeds and the green parts of plants) or three components. The mice most frequently

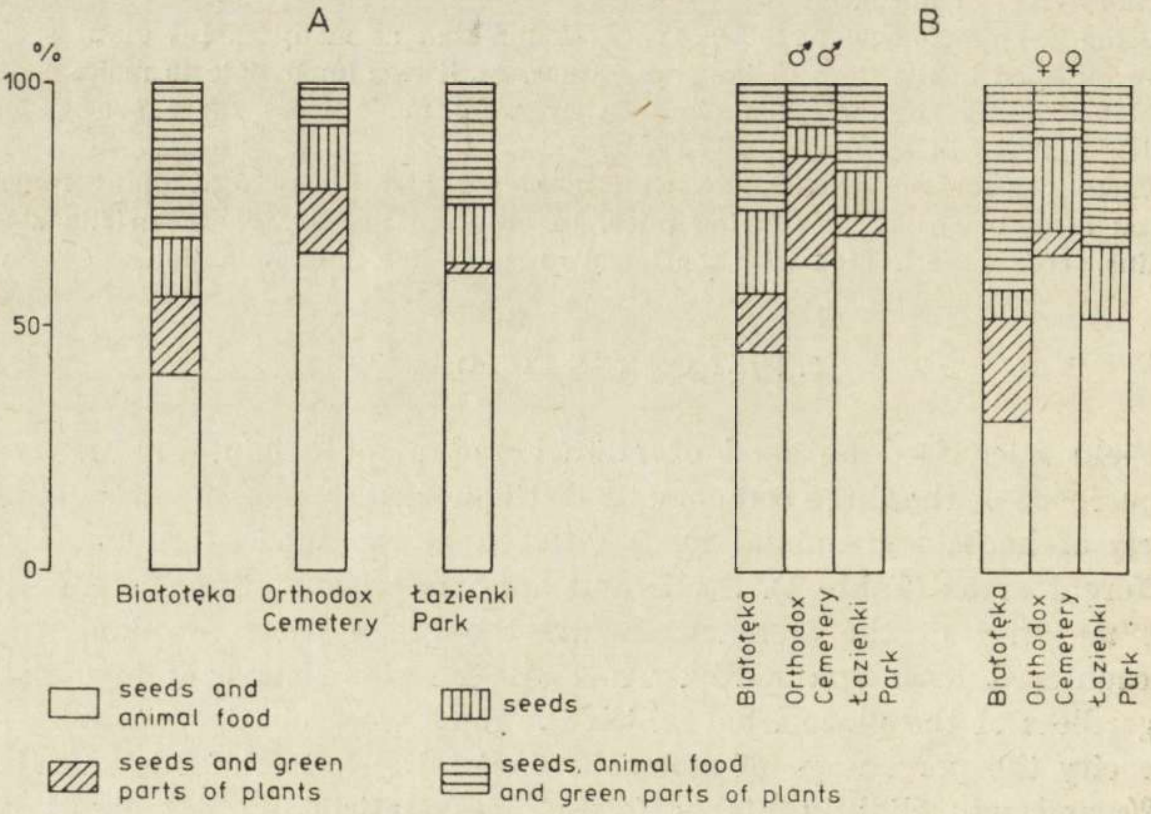

Fig. 1. Percentage in the study material of Apodemus agrarius stomachs containing different food fractions. A - all mice, B - division into males and females. 
fed on seeds and animal food, the percentage of stomachs obtained from urban mice containing food consisting of these two fractions being higher than at Białołęka (Fig. 1A). The most heterogeneous diet was found in mice from Białołęa, where the percentage of stomachs containing three food fractions was greater than in the city. On the other hand, diet consisting of two fractions predominated in mice from the city. $13 \%$ of the stomachs from all the study areas were filled solely with seeds.

Females consumed more varied food, and a higher percentage of their stomachs was found with three food fractions, whereas the diet of males consisted mainly of two components (Fig. 1B).

Volume of different food fractions in the stomachs was also examined. The measure of volume was expressed as percentage of the field of vision under the microscope eyepiece covered by the given fraction (mean value from 10 fields of vision). It was found that seeds formed the chief component of the field mouse's diet. They constitute $86-90 \%$ of the food volume (Fig. 2). Animal food forms $8-12 \%$ of the volume of stomach contents. Urban mice consumed slightly more seeds and less animal food than suburban ones. Apodemus agrarius supplemented its diet with the green parts of plants which formed approximately $1 \%$ of the volume of the stomachs irrespectively of the place from which the mice were obtained. Sand and small stones, forming $1 \%$ of stomach volume, were also found in the stomachs of the majority of these rodents.
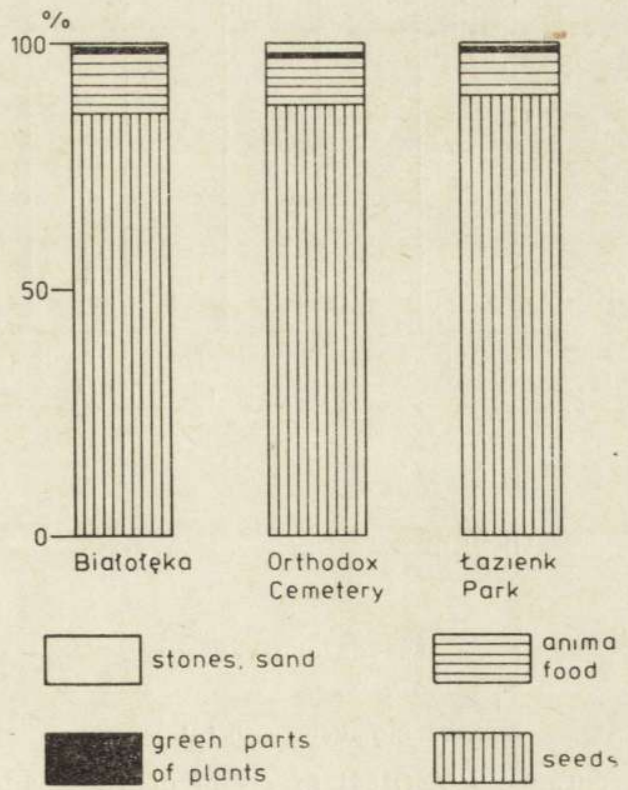

Fig. 2. Different food fractions (in \%) in stomachs contents of Apodemus agrarius. Acta theriol., 2 
Seasonal analysis of volume of three food fractions in the stomachs of males and females separately was also made. No statistically significant differences between sexes and seasons were found, although there was slight an increase in the seed fraction during the period from spring to winter, and a decrease in the percentage of animal food.

\section{PLANT FOOD}

Plant food consumed by field mice was classified into two fractions: seeds and the vegetative parts of herbs. Their importance for the rodents was not identical. The basis of the rodents' diet consisted of seeds, while the green parts of plants played only supplementary role.

\subsection{Seeds}

In the Apodemus agrarius stomachs seeds of 18 plant species belonging to 15 families were found (Table 2). This includes eight species of trees and ten species of herbs and grasses. In $52.4 \%$ of the stomachs examined
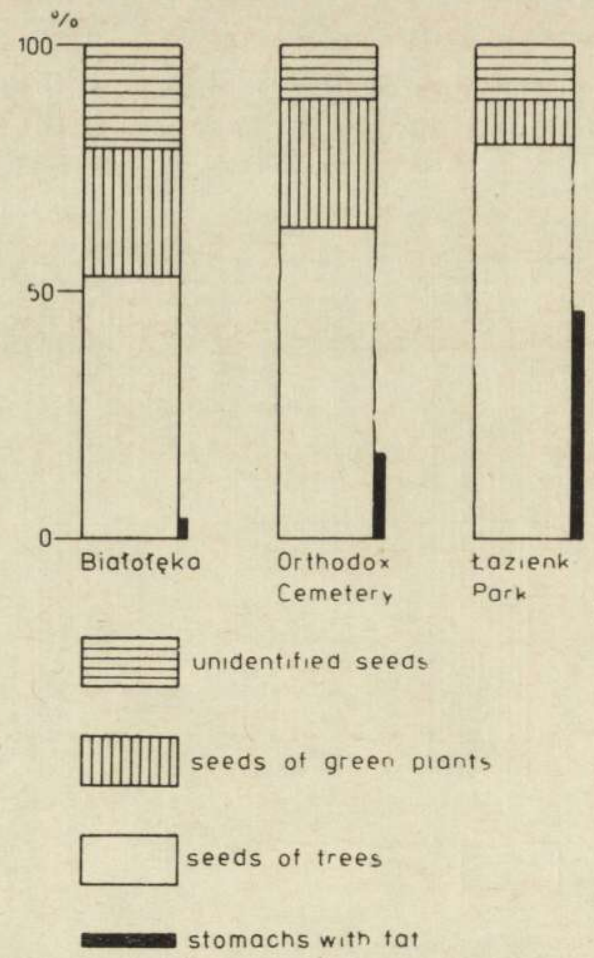

Fig. 3. Percentage occurence $[(f / \Sigma f) 100]$ of seeds of trees and herb layer plants in the stomachs of field mice. 
Table 2

Relative frequency $(\% \mathrm{f})$ of seeds (A) and green parts of plants (B) in the diet of Apodemus agrarius living in different urban green areas.

\begin{tabular}{|c|c|c|c|c|c|c|}
\hline & \multicolumn{2}{|c|}{ Białołęka } & \multicolumn{2}{|c|}{$\begin{array}{l}\text { Orthodox } \\
\text { Cemetery }\end{array}$} & \multicolumn{2}{|c|}{$\begin{array}{l}\text { Eazienki } \\
\text { Park }\end{array}$} \\
\hline & A & $\mathrm{B}$ & A & $\mathrm{B}$ & A & B \\
\hline $\begin{array}{l}\text { Rosaceae } \\
\text { Rosa arvensis Huds. }\end{array}$ & 1.54 & & & & & \\
\hline $\begin{array}{l}\text { Papilionaceae } \\
\text { Robinia pseudoacacia }\end{array}$ & & & & & & \\
\hline $\begin{array}{l}\text { Cruciferae } \\
\text { Berteroa incana }\end{array}$ & 6.15 & & 5.19 & & & \\
\hline $\begin{array}{l}\text { Berteroa incana L. } \\
\text { Capsella bursa-pastoris L. }\end{array}$ & 3.08 & 9.37 & 2.60 & & 2.38 & 27.27 \\
\hline $\begin{array}{l}\text { Tiliaceae } \\
\text { Tilia cordata Mill. }\end{array}$ & 20.0 & & 31.17 & & 16.70 & \\
\hline $\begin{array}{l}\text { Geraniaceae } \\
\text { Geranium pratense L. }\end{array}$ & & 18.75 & & & & \\
\hline $\begin{array}{l}\text { Aceraceae } \\
\text { Acer platanoides L. } \\
\text { Hippocastanaceae }\end{array}$ & 23.8 & & 37.66 & & 59.52 & \\
\hline $\begin{array}{l}\text { Hippocastanaceae } \\
\text { Aesculus hippocastanum L. } \\
\text { Fagaceae }\end{array}$ & 15.38 & & 24.67 & & 19.05 & \\
\hline $\begin{array}{l}\text { Fagaceae } \\
\text { Quercus sp. } \\
\text { Polygonaceae }\end{array}$ & 16.92 & & 5.19 & & 30.95 & \\
\hline Polygonum sp. & 20.15 & & 18.18 & & 11.90 & \\
\hline $\begin{array}{l}\text { Rumex sp. } \\
\text { Polygonum lapathifolium L. }\end{array}$ & & 3.12 & 1.30 & & & \\
\hline $\begin{array}{l}\text { Caryophyllaceae } \\
\text { Melandrium album Mill. }\end{array}$ & & & 1.30 & & & \\
\hline $\begin{array}{l}\text { Melandrium album Mill. } \\
\text { Stellaria media L. } \\
\text { Oleaceae }\end{array}$ & & 25.00 & & 5.55 & & \\
\hline $\begin{array}{l}\text { Fraxinus excelsior L. } \\
\text { Caprifoliaceae }\end{array}$ & 1.54 & & 1.30 & & & \\
\hline $\begin{array}{l}\text { Sambucus nigra L. } \\
\text { Amaranthae }\end{array}$ & 1.54 & & 1.30 & & & \\
\hline $\begin{array}{l}\text { Amaranthus retroflexus L. } \\
\text { Labiatae }\end{array}$ & & 3.12 & & & & \\
\hline $\begin{array}{l}\text { Glechoma hederacea L. } \\
\text { Solanaceae }\end{array}$ & & 3.12 & & 5.55 & & \\
\hline $\begin{array}{l}\text { Solanum nigrum L. } \\
\text { Scrophulariaceae }\end{array}$ & 7.69 & & 2.60 & & 7.14 & \\
\hline $\begin{array}{l}\text { Veronica sp. } \\
\text { Vebrascum sp. }\end{array}$ & 1.54 & & 1.30 & 11.11 & & \\
\hline Compositae & & & & & & \\
\hline $\begin{array}{l}\text { Arthemisia vulgaris L. } \\
\text { Xanthium strumarium L. }\end{array}$ & 3.08 & & $\begin{array}{l}1.30 \\
1.30\end{array}$ & & 2.38 & \\
\hline Taraxacum officinale Web. & & 12.50 & & & & \\
\hline $\begin{array}{l}\text { Sonchus arvensis L. } \\
\text { Lapsana communis L. }\end{array}$ & & $\begin{array}{l}3.12 \\
3.12\end{array}$ & & 5.55 & & 9.09 \\
\hline Artemisia vulgaris L. & & $\begin{array}{l}3.12 \\
3.12\end{array}$ & & & & \\
\hline $\begin{array}{l}\text { Gramineae } \\
\text { Dactylis glomerata L. }\end{array}$ & & 3.12 & 5.19 & & & 27.27 \\
\hline $\begin{array}{l}\text { Echinochloa crusgalli L. } 1 \\
\text { Setaria sp. } 1\end{array}$ & 6.15 & & 9.09 & & 4.76 & \\
\hline Lolium perenne L. & & & & 22.22 & & 27.27 \\
\hline Avena fatua $\mathrm{L}$. & & & & 5.55 & & 9.09 \\
\hline Epidermis of leaves & & & & & & \\
\hline and grass stalks, indet. & & 6.25 & & 38.89 & & 36.36 \\
\hline Green parts of plant, indet. & & 47.87 & & 33.33 & & 9.09 \\
\hline Seeds, indet. & & 23.08 & & 14.28 & & \\
\hline
\end{tabular}

1 Impossible to distinguish seeds. 
only seeds of one plant species was found, in $36.8 \%$ - of two species, and in the remainder of three $\left(8.6^{0} \%\right)$ or more species $\left(2.2^{\%} \%\right)$. This is evidence that mice usually ate the most easily accessible kind of seeds. This is also confirmed by the results of the studies by Holišová (1971), Hansson (1971).

Preference of certain kinds of seeds was established by means of the relative frequency index — \% (Obrtel \& Holišová, 1974). This index gives the percentage of stomachs containing particular seeds, assuming that all the stomachs containing food form $100 \%$. The seeds most often eaten by mice were those of: Acer platanoides, Tilia cordata, Aesculus hippocastanum and Quercus sp. (Table 2). The proportion of these seeds in the diet of urban mice was higher than in the diet of mice at Białołęka, which additionally consumed seeds of such trees as Robinia pseudoacacia, Fraxinus excelsior, Sambucus nigra and others. Various species, Polygonum sp. and Solanum nigrum, predominated among the seeds of herb layer plants found in the rodents' stomachs. Seeds of Echinochloa crus-galli and Setaria sp. were also frequently consumed. At Białołęka the number of species of herb layer seeds found in the rodents' stomachs was higher than in the city. This was not due to the greater diversity of the flora in the suburban area, since both the number of herb species and of tree species were comparable in all the study areas.

The proportion of tree seeds and herb layer plant seeds in the diet of Apodemus agrarius was calculated by means of the percentage occurrence index (Obrtel \& Holišová, 1974). This index is the percentage of each major component in the total sum of frequency, considered to be $100 \%$. Tree seeds formed the basic component of the rodents' diet (Fig. 3). Percentage occurrence of these seeds in the stomachs of urban mice reached as much as $80 \%$, whereas in the case of rodents from suburban areas this figure was only $54 \%$. The seeds of herb layer plants were in 9 to $26 \%$ of stomachs, their percentage occurrence in the stomachs of mice from urban areas being almost twice smaller than in suburban mice.

Examination was made of diversity of seeds in the diet of Apodemus agrarius living in the study areas. Diversity of the seeds in the rodents' food was calculated by the Shannon-Wiener index (Cox, 1967) $H=\Sigma p_{i} \ln p_{i}$, where it was taken that $H=$ index of species diversity, $p_{i}$ fraction of the given species of seeds in the number of seeds of all species. This index was calculated separately both for tree seeds and seeds of herb layer plants. In both cases it was higher for mice from suburban areas than for urban mice (tree seeds: Białołęka 1.64, Cemetery 1.46, Łazienki 1.25 and the seeds of herb layer plants: $1.96,1.63,1.43$ ). Thus the diet of mice from suburban areas included a greater variety of 
seeds than that of urban mice, which had a more homogenous diet. Variety of seed species occuring in the urban and suburban study areas is smilar, as far as the number of different plant species are considered. But their relative frequency was not examined, though the less variable, seed diet of urban rodents might be caused by less frequent occurrence of some seeds in urban habitat.

\subsection{The Vegetative Parts of Herb Layer Plants}

The diet of field mice was supplemented by the vegetative upper parts of herb layer plants. They formed only $1 \%$ of the volume of the food consumed by these rodents (Fig. 2) and were found in about $50 \%$ stomachs of suburban mice and only in $25 \%$ of stomachs of urban mice (Table 1). The mice most often consumed only one species of plant: Bialołkeka $-68.7 \%$ of the stomachs examined, and city (Cemetery and Łazienki jointly on account of the small amount of material) $-75.9 \%$. Less often two species of plants were eaten: Białołęka - 21.9\%, city $24.1 \%$. At Białołęka some rodents with three or four plant species in their stomachs were found $(9.4 \%)$, while none such rodent was found

- in town. This shows that mice from suburban areas exhibit a greater variety of their diet.

The fact that suburban mice consume a greater variety of plant species is also shown by the total number of plant species found in the stomachs of all rodents from the given-area, for instance from 6 to 7 species of plants were found in the stomachs of urban mice, and at Białołęka as many as 12 species. Urban mice most often consumed different plants of the Graminea family and Capsella bursa-pastoris (Table 2), whereas Stellaria media and Geranium pratense predominated in the stomachs of suburban mice, and the percentage of grasses was small.

The percentage occurrence of herb layer plants was calculated in the diet of these rodents (Fig. 4). Grasses were most often encountered in the stomachs of urban mice, occurring in $50 \%$ of the stomachs containing the herb layer plant fraction. In diet of suburban mice no predominant plant species was found, and much greater diversity of plants was stated. Confirmation of this is also provided by the fact that the percentage of unidentified plants was greater in the case of suburban mice, which could be caused by the difficulty in identifying them, as they probably belong to a large number of taxonomic groups. The ShannonWiener index shows that the diet of suburban mice is more diverse in its herb layer plant component (Fig. 4). The index value is lower in the city (treating the Cemetery and Eazienki Park jointly on account 


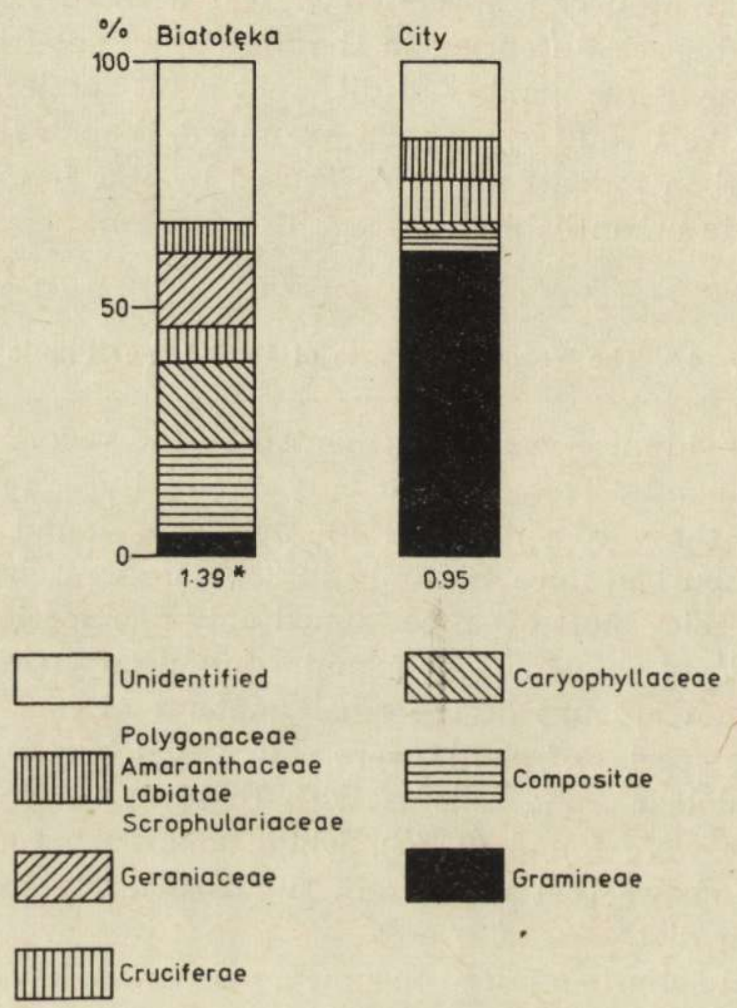

Fig. 4. Percentage occurrence $[(f / \Sigma f) 100]$ of herb layer plants in the stomachs of Apodemus agrarius.

* Index of diversity (Shannon-Wiener) of herb plant species in the rodents' stomachs.

of the small amount of material) than in the suburban area. Thus the mice living in the city also have a more homogenous fraction composed of herb layer plants in their diet than the suburban mice.

\section{ANIMAL COMPONENTS OF DIET}

Animal components of food were found in $71-84 \%$ of the rodents' stomachs, the percentage of this fraction being higher in urban than in suburban mice (Table 1). Animal food consumed by Apodemus agrarius consists primarily of invertebrates, whereas vertebrates (muscle tissue, feathers, fur) formed only $4 \%$ of the whole animal food.

Detailed studies of the composition of animal components, their significance in the food of the field mouse are presented in the paper by 
Babińska-Werka \& Garbarczyk (1981). Animal food most often consumed by these mice consisted of Insecta (dominating component), Aranea and Chilopoda. The proportion of insects was higher in the diet of Apodemus agrarius in the city, while the proportion of Aranea and Chilopoda was lower than in the suburban area. Among Insecta the dominant group consisted of caterpillars (Lepidoptera and Hymenoptera Symphyta larvae) while Coleoptera were second in importance. Diptera representatives were more numerous in the city than of Białołęka. Generally, the larval forms of Insecta were slightly more often encountered in the animal food of urban than suburban mice.

To sum up, it appears that field mice living in the city more readily and more often consume animal food than mice from suburban areas. At the same time they have a more homogenous animal fraction of the diet, since insects, and particularly their larval forms, predominate in the animal food they consume.

\section{ESTIMATING THE CALORIFIC VALUE OF FOOD}

During analysis of all the food fractions consumed by field mice the question arose as to whether there were differences in the calorific value of food consumed by these rodents living in towns and in more natural (suburban) habitats. According to Obrtel \& Holišová (1979), Hansson (1971) high-calorie food are seeds and animals as they are rich in carbohydrates and fats.

The most important component in the diet of field mice consisted of seeds. Apodemus agrarius more often fed on seeds of trees than those of herb layer plants (Fig. 3). Among tree seeds the rodents most often consumed such species as Acer platanoides, Tilia cordata, Aesculus hippocastanum, Quercus sp. Grodziński \& Sawicka-Kapusta (1970) state that the calorific value of these seeds varies within limits of $5.5-6.0 \mathrm{kcal} / \mathrm{g}$ of dry mass, while, as shown by Falinska's studies (1969), the seeds of herb layer plants have a caloric value from 3.4 to $6.1 \mathrm{kcal} / \mathrm{g}$ of dry mass. The percentage of tree seeds of higher caloric value in the diet of urban rodents was higher than in that of suburban mice (city $-80 \%$, Białołęka - 54\%) (Fig. 3). At the same time urban mice less often consume the seeds of herb layer plants.

A second high-calorie component in the diet of field mice consists of the larval forms of insects, such as caterpillars (Hymenoptera Symphyta and Lepidoptera) and Diptera larvae. Their percentage in the food of Apodemus agrarius is slightly higher in the city and reached as much as $59 \%$, whereas at Białołęka the larval forms formed $50 \%$ of all insects encountered in the rodents' stomachs (Fig. 5). 
When stomach contents were examined under a microscope floating droplets of fat could be seen, but unfortunately it proved impossible to state their origin. This might have been fat from vegetable or animal tissues consumed by rodents, or fat originating from the human food remnants found by rodents in the city. At Białolęka only $4 \%$ of the stomachs contained this food element (Fig. 3). In the Cemetery $17 \%$ of the stomachs contained fat, and in Łazienki Park as many as $46 \%$. It is thus clear that the presence of fat in the stomachs of Apodemus agrarius was distinctly more frequent in the city, and it can therefore be concluded that mice living in the city consume more caloric food than mice from suburban areas.

\section{DISCUSSION}

Apodemus agrarius is a species consuming high-calorie food, that is, chiefly seeds and invertebrates (Voronov, 1954), and indeed, as shown by the results obtained in the present study, seeds and invertebrates form the chief source of the food of this species. Similar results were obtained by Holišová (1967), who stated that seeds form the most important component of food of the field mouse. Other species of mice also feed on these two most caloric food fractions, but the proportions of animal food in their diet is different. For instance it is invertebrates (chiefly insects) which predominate over the seeds of both trees and herb layer plants in the food of Apodemus flavicollis and Apodemus sylvaticus (Obrtel \& Holišová, 1979, 1980).

The field mouse's food was thus chiefly formed by seeds, which were found in all the stomachs examined (Table 1). This agrees with the data given by Holišová (1967), who found that frequency of seeds in the rodents' stomachs was as much as $93 \%$, and animal components up to $68 \%$. In suburban areas at Białołęka frequency of animal food was $71 \%$, but in the city this figure was as great as $84 \%$. This may be due to the smaller proportion of seeds of herb layer plants in the diet of urban mice (Fig. 3). The rodents make up for this by greater consumption of tree seeds and invertebrates. This is evidence of the great adaptability of the field mouse and the ease with which it can switch to currently abundant food, as has been previously observed by Hansson (1971) in several species of rodent.

The results obtained in the present study show quite clearly that Apodemus agrarius, living in a city and undergoing the process of synurbization, feeds on food less diversified than individuals of the same species living in suburban areas. The homogenity of the food of urban 
mice was ascertained by analyzing all three food fractions, that is, seeds, green parts of plants and animal food. In the city, as compared with Białołęa, the mice more often consumed tree seeds, and less frequently seeds of herb layer plants (Fig. 3). In the city the twice smaller frequency of consuming the seeds of herb layer plants can be explained by the lower production in urbanized areas of such seeds, due to mowing grass plots and using herbicides. On the other hand the increase in consumption of tree seeds may be due to the concentration in city parks of many species of trees producing seeds readly eaten by these rodents.

Although the green parts of plants were only a supplementary element in their diet, in the case of urban mice they formed a very homogenous fraction, with the Gramineae family predominating, whereas in the case of mice from Białołęka this fraction was more diversified (Fig. 4). The volume of this food fraction in the stomachs is only $16 \%$, but formed an important component of their diet, since the vitamin contents in the green parts of plants play an important part in the nutrition of the animals (Voronov, 1954; Sahno, 1957; Holišová, 1967).

The animal food consumed by field mice living in the city was predominantly composed of insects, and to a lesser degree of Aranea and Chilopoda (Fig. 5). The total proportion of larval forms in the diet of urban mice was also greater than at Białołęka. Urban mice thus consumed chiefly Diptera, caterpillars and larvae of Diptera, and large, inactive and therefore easily accessible phytophages and saprophages. The latter applies to Coleoptera, which frequently exhibit a tendency to congregate. Spiders form a large proportion of the diet of Apodemus agrarius in addition to these animals. In the city the lower proportion of spiders and beetles in the rodents' diet can be explained by the lower density of these animals in the study area (Babińska-Werka \& Garbarczyk, 1981). The mice are therefore forced to change over to a different type of animal food - the kind most easily accesible, easy to catch or find and of high-calorie value. Caterpillars and larvae of Diptera form this type of food. Thus in the city the rodents' diet is more homogenous in respect of species composition than it is in suburban areas.

The fact that the mice consume high-calorie food, established by Voronov, 1954; Holišová, 1967; Obrtel \& Holišová, 1979, 1980; was also confirmed in the present study, urban mice feeding on more calorific food (Fig. 3,5 ) than mice from suburban areas.

Life under urban conditions in habitats different and greatly altered in comparison with natural habitats, brought about a change of diet in Apodemus agrarius. Diet of rodents living in the city was less diversified but more caloric, and this might have been the cause of the higher body weight of mice living in the city as compared with individuals of 
this species living in suburban areas, as found earlier by Andrzejewski et al. (1978).

Acknowledgements: The author wishes to thank Dr. R. Andrzejewski and Dr. J. Gliwicz for their valued comments on the text of this paper and also Dr. T. Gryczka for providing the phytosociological records and the lists of the flora of the study area.

\section{REFERENCES}

1. Andrzejewski R., Babińska-Werka J., Gliwicz J. \& Goszczyński J., 1978: Synurbization processes in population of Apodemus agrarius. I. Characteristics of population in an urbanization gradient. Acta theriol., 23: 341-358.

2. Babiński-Werka J., Gliwicz J. \& Goszczyński J., 1979: Synurbization processes in population of Apodemus agrarius. II. Habitats of striped field mouse in town. Acta theriol., 24: 405-415.

3. Babińska-Werka J., Gliwicz J. \& Goszczyński J., 1981: Demographic processes in an urban population of the striped field mouse. Acta theriol., 26: 275-283.

4. Babińska-Werka J. \& Garbarczyk H., 1981: Animal component of diet of striped field mouse under urban conditions. Acta theriol., 26: $301-318$.

5. Cox G. W., 1967: Laboratory manual for general ecology. Dubugue: 1-165. Iowa.

6. Drożdż A., 1966: Food habits and food supply of rodents in the beech forest. Acta theriol., 11: 363-384.

7. Falińska K., 1969: Zmienność wartości kalorycznej nasion niektórych gatunków grądowych w Białowieskim Parku Narodowym. Acta Soc. Botan. Pol., 37: $425-436$.

8. Gliwicz J., 1980: Ekologiczny aspekt synurbizacji myszy polnej Apodemus agrarius (Pall.). Wiad. Ekol., 26: 117-124.

9. Górecki A. \& Gębczyńska Z., 1962: Food conditions for small rodents in a deciduous forest. Acta theriol., 6: 275-295.

10. Grodziński W. \& Sawicka-Kapusta K., 1970: Energy values of tree-seeds eaten by small mammals. Oikos, 21: 52-58.

11. Holišová V., 1966: Food of an overcrowded population of the bank vole, Clethrionomys glareolus Schreb. in a lowland forest. Zool. Listy, 15: 207-224.

12. Holišová V., 1967: The food of Apodemus agrarius (Pall.). Zool. Listy, 16: $1-14$.

13. Holišová V., 1971: The food of Clethrionomys glareolus at different population densities. Acta Sc. Nat. Brno, 5: 1-43.

14. Hansson L., 1971: Small rodent food, feeding and population dynamics. Oikos, 22: $183-198$.

15. Naumov N. P., 1948: Očerki sravnitel'noj ekologi myševidnyh gryzunov. Izd. Akademi Nauk SSSR: 1-195, Moskva, Leningrad.

16. Obrtel R. \& Holišová V., 1974: Trophic niches of Apodemus flavicollis and Clethrionomys glareolus in a lowland forest. Acta Sc. Nat. Brno, 8: 1-37.

17. Obrtel R. \& Holišová V., 1979: The food eaten by Apodemus sylvaticus in a spruce monoculture. Folia Zool. Brno, 24: 299-310.

18. Obrtel R. \& Holišová V., 1980: The food eaten by Apodemus flavicollis in a spruce monoculture. Folia Zool., Brno, 29: 21-32. 
19. Roo-Zielińska E., (in press): Charakterystyka geobotaniczno-siedliskowa terenu projektowanego osiedla Bialołęka Dworska. [In: "Zoocenologiczne podstawy kształtowania środowiska przyrodniczego osiedla mieszkaniowego „Białołęka Dworska w Warszawie".] Fragm. Faun.

20. Sahno I. I., 1957: Materiały $\mathrm{k}$ izučeniju sostava kormov nekotorych myševidnych gryzunov. Zool. Ż., 36: 1084-1092.

21. Sviridenko P. A., 1944: Rasprostranienie, pitanie i epidemiologičeskoje značenie polevoj myši. Dokl. AN SSSR, 42: 96-100.

22. Voronov A. G., 1954: Osobennosti kormovogo raciona nekotoryh gryzunov. Zool. Ž., 33: 184-196.

Accepted, April 10, 1981.

\section{Joanna BABINSKA-WERKA}

\section{POKARM MYSZY POLNEJ ŻYJĄCEJ W ROŻNYCH TYPACH ZIELENI MIEJSKIEJ}

\section{Streszczenie}

Analize pokarmu myszy polnych przeprowadzono w Warszawie na dwóch terenach zieleni miejskiej: w Łazienkach i na Cmentarzu Prawosławnym oraz na terenie pozamiejskim w Białołęce. Zbadano 187 żołądków Apodemus agrarius stosując zmodyfikowaną metodę Holišovéj (Tabela 1). Na dietę myszy składały się nasiona, nadziemne wegetatywne części roślin zielnych oraz pokarm pochodzenia zwierzęcego. Pokarm roślinny przeważał nad pokarmem zwierzęcym, a dominującym komponentem w diecie myszy były nasiona (Tabela 2). Występowały one $u$ wszystkich badanych gryzoni, stanowiąc 86--90\% objętości żołądków (Ryc. 2). Myszy żyjące w mieście miały dietę bardziej jednorodną niż myszy z terenów pozamiejskich, co przejawiało się we wszystkich frakcjach pokarmu. Większy udzial nasion drzew $\mathrm{w}$ diecie myszy $\mathrm{z}$ jednocześnie rzadszym spożywaniem nasion roślin zielnych stwierdzono w mieście (Ryc. 3). Zielone części roślin zielnych stanowiły jedynie uzupelnienie diety Apodemus agrarius. U gryzoni miejskich charakterystyczny był fakt zdominowania tej frakcji pokarmu przez trawy (Ryc. 4). Pokarm zwierzęcy stanowił od 8 do $12 \%$ objętości żołądków i u myszy miejskich przeważały w nim owady, a wśród nich formy larwalne. Dieta myszy miejskich była nie tylko mniej urozmaicona niż myszy pozamiejskich, ale jednocześnie bardziej kaloryczna. Przejawiało się to dominacją nasion drzew i form larwalnych owadów oraz zawartością pływających kropli tłuszczu w żołądkach myszy (Ryc. 3). Większa kaloryczność pokarmu mogła być przyczyną wyższego ciężaru myszy w mieście w porównaniu do myszy pochodzących z terenów pozamiejskich. 